DOI: https://doi.org/10.32839/2304-5809/2019-12-76-30

УДК 808.51

Rozum Daryna

Nizhyn Gogol State University

\title{
UNIFICATION AND SEPARATION OF THE AMERICANS IN THE INAUGURAL SPEECHES OF B. OBAMA AND D. TRUMP
}

Summary. This article analyzes nomination of power relations representing unity and division of the nation in 2013 B. Obama's and 2017 D. Trump's inaugurals with the application of the conceptual relations for force. This paper draws on relations of attraction, enablement / disablement and blockage. It has been established that the idea of uniting the nation is transmitted by nominative units with the semantics of attraction. Both inaugurals split the nation into two classes: the upper and the lower. The meaning of the verbs that denote attaining success evokes the enablement of prosperity for the upper class, while verbs meaning opportunity loss trigger the disablement of lower class thriving. Verbs with the meaning of protection activate blockage relations underlying the presentation of the success of the upper class and supporting the opportunity loss of the lower class.

Keywords: power relations, inaugural, uniting the nation, dividing the nation, Barack Obama, Donald Trump.

Розум Д.В.

Ніжинський державний університет імені Миколи Гоголя

\section{ОБ’ЄДНАННЯ ТА РОЗ'СДНАННЯ АМЕРИКАНЦІВ В ІНАВГУРАЦІЙНИХ ПРОМОВАХ Б. ОБАМИ ТА Д. ТРАМПА}

Анотація. У статті проаналізовано мовні одиниці, які активують відношення сили, що ілюструють об’єднання та роз'єднання нації в інавгураційних промовах американських президентів Обами і Трампа. Для проведення дослідження застосовано апарат силових відношень, які включають притягання, забезпечення / позбавлення можливості і перешкоду. Визначено, що інавгураційні промови за своїм змістом належать до епідейктичного красномовства, оскільки їм властиві типові для цього виду промов якості, такі як церемоніальність, звернення до минулих, теперішніх та майбутніх подій та високий літературний стиль виголошення. Встановлено, що в обох промовах президенти звертаються до ідей об'єднання та роз'єднання нації. Головною метою об’єднання нації є показати американців як «Народ», тобто єдине ціле. Мовні одиниці, що позначають об’еднання нащії, пов’язані з відношеннями притягання: едність виражена іменниками та прийменниками, що відсилають до Америки та виступають джерелом притягання. Одиниці на позначення нації вказують на щіль відношень притягання. Визначено, що Обама застосовуе більш семантично яскраві дієслова, щоб проілюструвати об'єднання нації, ніж Трамп. Той фракт, що обидва президенти звертаються до ідеї роз'єднання нації, пояснюеться епідейктичним характером інавгураційних промов, який виявляеться у констатуванні протирічних фракторів навколишньої дійсності. В обох інавгуращійних промовах Америка розділена на два класи: вищий і нижчий. Значення діеслів, які називають здобуття успіху, пов'язане із забезпеченням можливості для вищого класу, в той час як дієслова на позначення втрати можливості ілюструють протилежні силові відношення, властиві нижчому класу. Діеслова зі значенням захисту активують відношення перешкоди, що уможливлюють успіх для вищого класу та посилюють його відсутність для нижчого. Доведено, що для Трампа ідея роз'єднання нащії носить більш вагомих характер, ніж для Обами, оскільки у його промові контраст між вищим і нижчим класом американського суспільства представлений більшою кількістю прикладів, а також семантично сильнішими мовними одиницями.

Ключові слова: відношення сили, інавгураційна промова, об'єднання нації, роз'єднання нації, Барак Обама, Дональд Трамп.

Problem setting. Political discourse is known to reveal its significant importance in our life due to the strong appeal to the audience so as to motivate people to act, to persuade them of correctness of the speaker's beliefs and ideas [11, p. 2408]. The inaugural as a kind of political discourse seeks to impose the president's political values and principles on the people. Every American president intends to persuade the addressee that he is fit for the position he takes, and that new political course will be more successful than the previous one [11, p. 2408].

The topicality of this study lies in distinguishing the effective means of persuading the people of the speaker's suitability for presidency, since persuasion first and foremost influences our mind evoking particular thoughts [14]. Therefore without the proper understanding of the mechanisms of our mind's work it is impossible to make an effective appeal to the audience. It is cognitive linguistics that explains the processes of human perception and thinking with the help of image schema apparatus, i.e. patterns stemming from the bodily experience of interaction with the surrounding reality [9, p. 19]. In their inaugurals, presidents rely on power relations represented by image schemas rendering the speaker's perception of the world and embodying the power relations evoked by lexical units in a speech. In a broader sense, the semantics of linguistic units reflects the actual intentions of the president and help us to understand his intentions.

Selection of the recently unsolved areas of the problem. It has been found, that there are relatively few studies of the American political discourse in general and inaugurals in particular. Considering the significant role American political oratory plays in the life of entire world, the necessity to analyze its means of persuasion is obvious. Conceptual relations for force help to reveal the patterns of the inaugurals and thus offer the deep understanding of the key ideas American presidents want to persuade the audience of. 
Literature review. Significant for this article are the original cognitive linguistic studies by M. Johnson [9], L. Talmy [17] and G. Lakoff [10] who laid the basis of the cognitive approach to linguistics. Image schemas and their role in our understanding and reasoning were explored by C. Forceville [4], B. Hampe [7] and P. Gärdenfors [5], who rethought and enriched the original definition of image schemata suggested by M. Johnson [9]. Peculiarities of American inaugurals as a kind of rhetorical addresses were put forward by K. Campbell and K. Jamieson [2; 3], D. Graham [6], L. Italiano [8], M. Ngai [13] and F. Liu [11]. We base our analysis on cognitive approach to studying inaugurals offered by S. Potapenko [16].

Task setting. This paper's main task is to single out lexical patterns of power relations that embody uniting and dividing the nation in Obama's and Trump's inaugurals.

Main body. According to K. Campbell and $\mathrm{K}$. Jamieson, the inaugural belongs to epideictic oratory [2, p. 396]. Aristotle viewed the epideictic address as a form of rhetorical address enunciated on ceremonial occasions, which appeals to an audience that, in its turn, evaluates the rhetor's skill $[1$, p. 2-4], recalls the past and speculates about the future while focusing on the present [1, p. 18-20], employs a noble, dignified and literary style [1, p. 15] and amplifies or rehearses admitted facts [1, p. 27]. Based on this definition the structure of inaugurals includes the so-called moves [11, p. 2409], i.e. parts of the text, written or spoken, which achieve a particular purpose within the speech [11, p. 2409].

Inaugurals are structured into the following moves: reconstituting "the People", rehearsing traditional values, enunciating political principles, enacting the presidency and fulfilling epideictic requirements [2, p. 396; 11, p. 2409]. Reconstituting "the People" move results in uniting the nation for the sake of ratifying the ascent to power [2, p. 396]. Being opposite to uniting the nation, dividing it embodies epideictic nature of the inaugurals, where resonant and controversial ideas rehearse admitted facts [2, p. 404] of the society split into the upper and lower classes. However, in Obama's and Trump's addresses, dividing the nation is subordinated to the idea of American unity, for they emphasize the necessity to form a new, stronger consolidation under their presidency.

Both uniting and dividing the nation moves are represented in Obama's and Trump's inaugurals by the linguistic units that express power relations stemming from force image schemas of attraction, enablement, disablement and blockage which consist of a source, a target and of a direction (vector) of an action [9, p. 42].

Uniting the nation is the main point of the beginning of the presidents' inaugurals.

Uniting the nation is evoked by the verbs with the semantics of bringing together resting on attraction relations. ATTRACTION represents a goal following the source $[9, \mathrm{p} .47]$. The source is represented by pronouns we and our and the adverb together. In President Obama's address, the object the nation stands for the target of attraction. In Trump's speech, the target of attraction is expressed by two levels: the level of the nation and the level of the establishment, denoted by the pronoun we, cf.
(1) Each time we gather to inaugurate a President we bear witness to the enduring strength of our Constitution. We affirm the promise of our democracy. We recall that what binds this nation together is not the colors of our skin or the tenets of our faith or the origins of our names (Obama [15]).

(2) We, the citizens of America, are now joined in a great national effort to rebuild our country and to restore its promise for all of our people (Trump [18]).

In the cited utterances from both presidents' inaugurals, uniting the nation is expressed by the predicates gather, binds and are joined that share the common meaning of putting together [12] and represent the vector of attraction relations. However, the predicate binds in Obama's inaugural expresses a greater degree of attraction, as to bind means to tie together [12], while to gather and to join in Trump's address stand for bringing together [12] being weaker in meaning.

Unity as the source and establishment as the target of attraction relations are expressed by the pronoun $w e$ in the next utterance from Trump's address:

(3) Every four years, we gather on these steps to carry out the orderly and peaceful transfer of power, and we are grateful to President Obama and First Lady Michelle Obama for their gracious aid throughout this transition (Trump [18]).

The position of the predicate gather that represents the vector of attraction relations, used in this utterance from Trump's address, differs from the Obama's (1) utterance. Obama starts uniting the nation with this predicate, and Trump uses gather to assemble the establishment at the end of the uniting move.

Dividing the nation shows the split of the Americans into two different entities opposed to each other: the upper and the lower classes.

The prosperity of the upper class is expressed by units with the meaning of success that activate the relation of enablement. ENABLEMENT is characterized by the presence of some inner force vector and the absence of any barriers and restraints for moving [9, p. 47]

The misery of the lower class is denoted by the verbs with the meaning of success absence that evoke the DISABLEMENT image schemas and by the units that denote obstacles to success based on the BLOCKAGE relations. DISABLEMENT reflects the inability to act [9, p. 47], and BLOCKAGE is formed by the vector of power, which stops or changes the trajectory of movement as a result of collision with a restraint $[9$, p. 45].

The opposition between the upper and lower classes is presented by the adversative conjunctions but and while.

The upper class is named by the units referring to small amount of people (the small group, few), to high society (Washington, politicians, the establishment), and the deictic units they and their. The lower class is verbalized by the units denoting a big amount of people (many), ordinary people (the people, the citizens, struggling families), and by the deictic unit your.

The privileged position of the upper class and the deprived status of the lower class are underlined by contrast between the linguistic units that express success and activate enablement and those that name the absence of success and thus point 
to disablement. Words and word combinations that name the upper class represent it as a source and a target of enablement, as well as a disablement source affecting the lower class, cf.

(4) For too long, a small group in our nation's Capital has reaped the rewards of government while the people have borne the cost. Washington flourished - but the people did not share in its wealth. Their victories have not been your victories; their triumphs have not been your triumphs; and while they celebrated in our nation's capital, there was little to celebrate for struggling families all across our land. (Trump [18]).

(5) For we remember the lessons of our past, when twilight years were spent in poverty and parents of a child with a disability had nowhere to turn (Obama [15]).

In the utterance from Obama's inaugural, the idea of the upper class prosperity is named by the subject victory and the predicate has reaped that express the meaning "to own something, be the owner" [12]; and by the subject triumph that means success: "to develop successfully, to honor success" [12] as well as the predicates flourished and celebrated. The idea of the lower class distress is represented by the predicative groups have borne the cost, did not share wealth, was little to celebrate, spent in poverty in Trump's inaugural, and by the attribute with a disability in Obama's address. These linguistic units mean misery and denote the vector of disablement relations for the lower class.

In Trump's inaugural, the dominating position of the upper class and the humiliating status of the lower class are strengthened by the predicates that express an obstacle to success for the lower class and support of success for the upper class. These units activate the blockage image schema. The upper class represents the source of blockage aimed at the lower class:

(6) Politicians prospered - but the jobs left, and the factories closed (Trump [18]).

In the cited paragraph from Trump's inaugural, the predicates left and closed express the shared meaning of blocking [12], since in this context, they refer to hampering employment for the lower class, and embodying the vector of blockage relations.

The support of the upper class' success is denoted by the predicates referring to protection evoking blockage relations:

(7) The establishment protected itself, but not the citizens of our country (Trump [18]).
In the utterance from Trump's speech, given above, the predicate protected names blockage relations stopping the undesirable forces and empowering success enablement for the upper class.

In Obama's inaugural, linguistic units denoting success enablement for the upper class form an opposition with the units referring to the opportunity disablement for the lower class. This opposition becomes the source of distress for the whole country:

(8) For we, the people, understand that our country cannot succeed when a shrinking few do very well and a growing many barely make it (Obama [15]).

In this utterance from Obama's address, the success enablement for the upper class is expressed by the predicative group do very well, while prosperity disablement for the lower class is represented by the predicative group barely make it. The predicate cannot succeed triggers opportunity disablement for the country.

Conclusions. In Obama's and Trump's inaugurals the nation's unity is expressed by linguistic units with the meaning of "putting the items together" that rest on attraction relations. In both addresses, unity is named by nouns and pronouns referring to America serving as a source of attraction. The nation's division into upper and lower classes is represented by the enablement-disablement opposition that rests upon two contrasting relations: enablement, that expresses the ability to act, and disablement, showing the inability to act. The high position of the upper class, depicted by the units with the semantics of small amount of people, is expressed by verbs denoting bringing success which rests on prosperity enablement. The miserable state of the lower class, named by the units with the semantics denoting big amount of people, is represented by the predicates with the meaning of the loss of opportunity triggering the disablement relations. The lexical units with the semantics of protection evoke blockage relations underlying the presentation of the success of the upper class. Units denoting obstacles to the advancement refer to the blockage relations. Perspectives for the further study include the complex analysis of both presidents' inaugurals and comparison of their power relations models in order to present what ideas Obama and Trump voice and how these ideas are named. Similar analysis can be applied for other presidents' inaugurals not only in America, but also in different countries. In this way, the cross-cultural comparison of political speaking can be conducted.

\section{References:}

1. Aristotle (2004). Rhetoric / translated by W.R. Roberts. Dover: Dover Publications.

2. Campbell, K.K., \& Jamieson, K.H. (1985). Inaugurating the Presidency. Presidential Studies Quarterly. Vol. 15, no. 2, pp. 394-411.

3. Campbell, K.K., \& Jamieson, K.H. (2008). Presidents Creating the Presidency. Deeds Done in Words. Chicago: University of Chicago Press.

4. Forceville, C. (2017). From image schema to metaphor and discourse: The FORCE schemas in animation films Metaphor: Embodied Cognition and Discourse, pp. 239-256.

5. Gärdenfors, P. (2007). Cognitive Semantics and Image Schemas with Embodied Forces. Embodiment in Cognition and Culture. Lund: John Benjamins Publishing Company, pp. 57-76.

6. Graham, D.A. (2017). 'America First': Donald Trump's Populist Inaugural Address. The Atlantic. Available at: https://www.theatlantic.com/politics/archive/2017/01/trump-inaugural-speech-analysis/513956/ (accessed: 22 November 2019).

7. Hampe, B. (2005). Image Schemas in Cognitive Linguistics. From Perception to Meaning. Erfurt: Erfurt University Press, pp. 1-13.

8. Italiano, L. (2017). Trump's inauguration speech was really, really short. New York Post. Available at: https://nypost.com/2017/01/20/trumps-inauguration-speech-was-really-really-short/ (accessed: 22 November 2019). 
9. Johnson, M. (1987). The Body in the Mind: The Bodily Basis of Meaning, Imagination, and Reason. Chicago; L.: The University of Chicago Press.

10. Lakoff, G. (1987). Women, Fire, and Dangerous Things: What Categories Reveal about the Mind. Chicago: University of Chicago Press.

11. Liu, F. (2012). Genre Analysis of American Presidential Inauguration Speech. Theory and Practice in Language Studies. Vol. 2, no. 11, pp. 2407-2411.

12. MW: Merriam-Webster Online: Dictionary and Thesaurus. Available at: https://www.merriam-webster.com/ (accessed: 22 November 2019).

13. Ngai, M. (2017). Donald Trump Inaugural Speech Analysis Linked to Politics and the English Language. Academia. Available at: https://www.academia.edu/35898723/Donald_Trump_Inaugural_Speech_Analysis_ Linked_to_Politics_and_the_English_Language_-_Orwell (accessed: 22 November 2019).

14. O'Keefe, D. (2007). Persuasion. Encyclopedia of rhetoric. Oxford: Oxford University Press, pp. 595-603.

15. Obama, B. (2013). Inaugural Address / online by G. Peters and J.T. Wooley. Available at: https://www.presidency. ucsb.edu/documents/inaugural-address-15 (accessed: 22 November 2019).

16. Potapenko, S. (2016). Cognitive rhetoric of effect: energy flow as a means of persuasion in inaugurals. Topics in Linguistics. Vol. 17(2), pp. 12-25.

17. Talmy, L. (2000). Force dynamics in language and cognition. Concept structuring systems. Language: The Journal of the Linguistic Society of America. Vol. 78(3), pp. 576-578.

18. Trump, D.J. (2017). Inaugural Address / online by G. Peters and J.T. Woolley. Available at: http://www.presidency. ucsb.edu/ws/index.php?pid=120000 (accessed: 22 November 2019). 